\title{
Antipsychotic-induced priapism: Mitigating the risk
}

Melissa Mitchell, PharmD, BCPP, BCPS, BCGP, Ana Barron, PharmD, BCPP, and Erika Kim, PharmD, BCPP

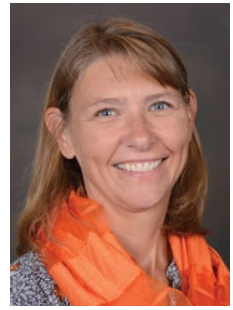

Vicki L. Ellingrod, PharmD, FCCP

Department Editor

Sawy Psychopharmacology is produced in partnership with the College of Psychiatric and Neurologic Pharmacists cpnp.org mhc.cpnp.org (journal)
$\mathrm{M}$ r. J, age 35 , is brought to the hospital from prison due to priapism that does not improve with treatment. He says he has had priapism 5 times previously, with the first incidence occurring "years ago" due to trazodone.

Recently, he has been receiving risperidone, which the treatment team believes is the cause of his current priapism. His medical history includes asthma, schizophrenia, hypertension, seizures, and sickle cell trait. Mr. $J$ is experiencing auditory hallucinations, which he describes as "continuous, neutral voices that are annoying." He would like relief from his auditory hallucinations and is willing to change his antipsychotic, but does not want additional treatment for his priapism. His present medications include risperidone, $1 \mathrm{mg}$ twice a day, escitalopram, $10 \mathrm{mg} / \mathrm{d}$, benztropine, $1 \mathrm{mg}$ twice a day, and phenytoin, $500 \mathrm{mg} / \mathrm{d}$ at bedtime.

Priapism is a prolonged, persistent, and often painful erection that occurs without sexual stimulation. Although relatively rare, it can result in potentially serious long-term complications, including impotence and

Dr. Mitchell is Assistant Director of Pharmacy, Riverside University Health System Medical Center, Moreno Valley, California. Dr. Barron is Clinical Pharmacist in Psychiatry, Riverside University Health System Medical Center, Moreno Valley, California. Dr. Kim is Clinical Pharmacist in Psychiatry and Geriatrics, Riverside University Health System, Moreno Valley, California.

\section{Disclosures}

Dr. Mitchell has served as a speaker for Janssen Pharmaceuticals and Neurocrine Biosciences, and received income from Otsuka Pharmaceutical. Drs. Barron and Kim report no financial relationships with any companies who products are mentioned in this article, or with manufacturers of competing products.

doi: $10.12788 /$ cp.0211 gangrene, and requires immediate evaluation and management.

There are 2 types of priapism: nonischemic, or "high-flow," priapism, and ischemic, or "low-flow," priapism (Table 1,1-3 page 41). While nonischemic priapism is typically caused by penile or perineal trauma, ischemic priapism can occur as a result of medications, including antipsychotics, antidepressants, anxiolytics, and antihypertensives, or hematological conditions such as sickle cell disease. ${ }^{1}$ Other risk factors associated with priapism include substance abuse, hyperprolactinemia, diabetes, and liver disease. ${ }^{4}$

\section{Antipsychotic-induced priapism}

Medication-induced priapism is a rare adverse drug reaction (ADR). Of the medication classes associated with priapism, antipsychotics have the highest incidence

\section{Practice Points}

- Minimize a patient's risk for priapism by thoroughly reviewing their medical history for any inherent priapism factors, such as sickle cell anemia, substance abuse, diabetes/uncontrolled blood glucose, hyperprolactinemia, or liver disease.

- Screen the patient's list of active medications to ensure that there are no potential drug interactions that may increase the risk of priapism.

- If a patient with psychotic illness experiences priapism, consider reducing the dose of the offending agent and/or switching to an antipsychotic with a lower alpha-adrenergic affinity. 


\section{Nonischemic vs ischemic priapism: A comparison}

\begin{tabular}{|c|c|c|}
\hline Factor & Nonischemic & Ischemic \\
\hline $\begin{array}{l}\text { Characterization of } \\
\text { associated blood flow }\end{array}$ & High-flow & Low-flow \\
\hline $\begin{array}{l}\text { Mechanism by which } \\
\text { it occurs }\end{array}$ & $\begin{array}{l}\text { Secondary to unregulated } \\
\text { blood entry and filling of the } \\
\text { corpora cavernosa }\end{array}$ & $\begin{array}{l}\text { Secondary to reduced or absent } \\
\text { intracorporeal blood flow most probably } \\
\text { caused by dysregulation of penile erection }\end{array}$ \\
\hline Cause(s) & Penile or perineal trauma & $\begin{array}{l}\text { Medications (antidepressants, } \\
\text { antipsychotics, antihypertensives), } \\
\text { hematologic disorders, alcohol }\end{array}$ \\
\hline Other considerations & $\begin{array}{l}\text { Usually resolves } \\
\text { spontaneously and typically } \\
\text { not associated with hypoxia } \\
\text { and ischemia of the penile } \\
\text { vascular tissue }\end{array}$ & $\begin{array}{l}\text { Typically considered a urologic emergency } \\
\text { requiring immediate intervention } \\
\text { Can lead to long-term devastating } \\
\text { consequences, such as impotence, urinary } \\
\text { retention, and gangrene }\end{array}$ \\
\hline
\end{tabular}

\section{Table 2}

\section{Comparison of various antipsychotics' affinity for} alpha- 1 adrenoceptors

\begin{tabular}{|c|c|c|}
\hline & Antipsychotic & $\begin{array}{c}\text { Affinity for alpha-1 } \\
\text { adrenoceptors }\end{array}$ \\
\hline \multirow{7}{*}{$\begin{array}{l}\text { Antipsychotics with high affinity for } \\
\text { alpha-1 adrenoceptors }(>10.0)\end{array}$} & Ziprasidone & 38.5 \\
\hline & Chlorpromazine & 38.5 \\
\hline & Risperidone & 37.0 \\
\hline & Thioridazine & 20.0 \\
\hline & Clozapine & 14.7 \\
\hline & Quetiapine & 12.0 \\
\hline & Fluphenazine & 11.1 \\
\hline \multirow{10}{*}{$\begin{array}{l}\text { Antipsychotics with low/medium affinity } \\
\text { for alpha- } 1 \text { adrenoceptors }(\leq 10.0)\end{array}$} & Perphenazine & 10.0 \\
\hline & Paliperidone & 9.9 \\
\hline & Haloperidol & 5.9 \\
\hline & Droperidol & 5.3 \\
\hline & Prochlorperazine & 4.2 \\
\hline & Trifluoperazine & 4.2 \\
\hline & Aripiprazole & 3.9 \\
\hline & Loxapine & 3.6 \\
\hline & Olanzapine & 1.9 \\
\hline & Pimozide & 1.3 \\
\hline
\end{tabular}

and account for approximately $20 \%$ of all cases. ${ }^{1}$

The mechanism of priapism associated with antipsychotics is thought to be related to alpha-1 blockade in the corpora cavernosa of the penis. Although antipsychotics within each class share common characteristics, each agent has a unique profile of receptor affinities. As such, antipsychotics have varying affinities for the alpha-adrenergic receptor (Table $2^{2}$ ). Agents such as ziprasidone, chlorpromazine, and risperidone-which have the highest affinity for the alpha-1

\section{Clinical Point}

Priapism as a result of antipsychotic use may be related to alpha-1 blockade in the corpora

\section{cavernosa}

Discuss this article at www.facebook.com/ MDedgePsychiatry (6) 


\section{Clinical Point}

\section{Among antipsychotics, ziprasidone, chlorpromazine, and risperidone may be more likely to cause priapism}

Table 3

Clinically relevant antipsychotic substrates for metabolism by CYP1A2, CYP2D6, and CYP3A4 enzymes

\begin{tabular}{l|l|l|l}
\hline First-generation antipsychotics & CYP1A2 & CYP2D6 & SYP3A4 \\
\hline Haloperidol & Substrate & Substrate & Substrate \\
\hline Fluphenazine & Substrate & & \\
\hline Chlorpromazine & Substrate & & \\
\hline Perphenazine & & Substrate & Substrate \\
\hline Pimozide & Substrate & & \\
\hline Thioridazine & & Substrate & CYP3A4 \\
\hline Second-generation antipsychotics & CYP1A2 & CYP2D6 & Substrate \\
\hline Aripiprazole & & Substrate & \\
\hline Asenapine & Substrate & & Substrate \\
\hline Clozapine & Substrate & Substrate & \\
\hline Olanzapine & Substrate & Substrate & \\
\hline Paliperidone & & & Substrate \\
\hline Risperidone & & Substrate & Substrate \\
\hline Quetiapine & & Substrate & Substrate \\
\hline Ziprasidone & & & Substrate \\
\hline Iloperidone & & & \\
\hline $\begin{array}{l}\text { CYP: cytochrome P450 } \\
\text { Source: Adapted from references 5,6 }\end{array}$ & & & \\
\hline
\end{tabular}

adrenoceptors-may be more likely to cause priapism compared with agents with lower affinity, such as olanzapine. Priapism may occur at any time during antipsychotic treatment, and does not appear to be dose-related. ${ }^{1}$

\section{Antipsychotic drug interactions and priapism}

Patients who are receiving multiple medications as treatment for chronic medical or psychiatric conditions have an increased likelihood of experiencing drug-drug interactions (DDIs) that lead to adverse effects.

Various case reports have described priapism as a result of DDIs related to antipsychotic agents combined with other psychotropic or nonpsychotropic medications. ${ }^{3}$ Most of these DDIs have been attributed to the cytochrome P450 (CYP) family of enzymes, including CYP2D6, CYP1A2, and CYP3A4/5, which are major enzymes implicated in the metabolism of antipsychotics (Table $3^{5,6}$ ).
It is imperative to be vigilant during the concomitant administration of antipsychotics with other medications that may be substrates, inducers, or inhibitors of CYP enzymes, as this could alter the metabolism and kinetics of the antipsychotic and result in ADRs such as priapism. For example, drug interactions exist between strong CYP2D6 inhibitors-such as the antidepressants paroxetine, fluoxetine, and bupropion-and antipsychotics that are substrates of CYP2D6, such as risperidone, aripiprazole, haloperidol, and perphenazine. This interaction can lead to higher levels of the antipsychotic, which would increase the patient's risk of experiencing ADRs. Because psychotic illnesses and depression/anxiety often coexist, it is not uncommon for individuals with these conditions to be receiving both an antipsychotic and an antidepressant.

Because there is a high incidence of comorbidities such as HIV and cardiovascular disease among individuals with 
mental illnesses, clinicians must also be cognizant of any nonpsychotropic medications the patient may be taking. For instance, clinically relevant DDIs exist between protease inhibitors, such as ritonavir, a strong CYP3A4 inhibitor, and antipsychotics that are substrates of CYP3A4, such as pimozide, aripiprazole, and quetiapine. ${ }^{5}$

\section{Mitigating the risk of priapism}

Although there are associated risk factors for priapism, there are no concrete indicators to predict the onset or development of the condition. The best predictor may be a history of prolonged and painless erections. ${ }^{3}$

As such, when choosing an antipsychotic, it is critical to screen the patient for the previously mentioned risk factors, including the presence of medications with strong alpha-1 receptor affinity and CYP interactions, especially to minimize the risk of recurrence of priapism in those with prior or similar episodes. Management of patients with priapism due to antipsychotics has involved reducing the dose of the offending agent and/or changing the medication to one with a lower alpha-adrenergic affinity (Table 2, ${ }^{2}$ page 41 ).

Similar to most situations, management is patient-specific and depends on several factors, including the severity of the patient's psychiatric disease, history/severity of priapism and treatment, concurrent medication list, etc. For example, although clozapine is considered to have relatively high affinity for the alpha-1 receptor, it is also the agent of choice for treatmentrefractory schizophrenia. Risks and benefits must be weighed on a individualized basis. Case reports have described symptom improvement via lowering the dose of clozapine and adding on or switching

\section{Related Resources}

- Levey HR, Segal RL, Bivalacqua TJ. Management of priapism: an update for clinicians. Ther Adv Urol. 2014;6(6):230-244. doi:10.1177/1756287214542096

- Salonia A, Eardley I, Giuliano F, et al. Guidelines on priapism. European Association of Urology. https://uroweb.org/ guideline/priapism

Drug Brand Names

Aripiprazole • Abilify

Benztropine - Cogentin

Bupropion - Wellbutrin

Chlorpromazine - Thorazine

Clozapine - Clozaril

Escitalopram • Lexapro

Fluoxetine - Prozac

Fluphenazine - Prolixin

Haloperidol • Haldol

lloperidone - Rexulti

Loxapine - Loxitane

Olanzapine - Zyprexa

\author{
Paliperidone - Invega \\ Paroxetine - Paxil \\ Perphenazine - Trilafon \\ Phenytoin - Dilantin \\ Pimozide - Orap \\ Prochlorperazine - Compazine \\ Quetiapine - Seroquel \\ Risperidone • Risperdal \\ Thioridazine - Mellaril \\ Trifluoperazine • Stelazine \\ Ziprasidone - Geodon
}

to an antipsychotic agent with minimal alpha-1 receptor affinity. ${ }^{4}$

\section{CASE CONTINUED}

After considering Mr. J's history, risk factors, and preferences, the treatment team discontinues risperidone and initiates haloperidol, $5 \mathrm{mg}$ twice a day. Soon after, Mr. J no longer experiences priapism.

\section{References}

1. Weiner DM, Lowe FC. Psychotropic drug-induced priapism. Mol Diag Ther 9. 1998;371-379. doi:10.2165/00023210199809050-00004

2. Andersohn F, Schmedt N, Weinmann S, et al. Priapism associated with antipsychotics: role of alpha1 adrenoceptor affinity. J Clin Psychopharmacol. 2010;30(1):68-71. doi:10.1097/ JCP.0b013e3181c8273d

3. Sood S, James W, Bailon MJ. Priapism associated with atypical antipsychotic medications: a review. Int Clin Psychopharmacol. 2008;23(1):9-17.

4. Sinkeviciute I, Kroken RA, Johnsen E. Priapism in antipsychotic drug use: a rare but important side effect. Case Rep Psychiatry. 2012;2012:496364. doi:10.1155/2012/496364

5. Mora F, Martín JDD, Zubillaga E, et al. CYP450 and its implications in the clinical use of antipsychotic drugs. Clin Exp Pharmacol. 2015;5(176):1-10. doi:10.4172/2161-1459.1000176

6. Puangpetch A, Vanwong N, Nuntamool N, et al. CYP2D6 polymorphisms and their influence on risperidone treatment. Pharmgenomics Pers Med. 2016;9:131-147. doi:10.2147/PGPM. S107772

\section{Clinical Point}

Screen patients

for the use of medications with strong alpha-1 receptor affinity and/or potential CYP interactions 